Indonesian Journal of Social Sciences Volume 12 No. 02, July - December 2020, page 85-95

\title{
Shifting the use of Leuit in agricultural systems
}

\author{
Ani Fathurohmah \& Djoko Adi Prasetyo \\ Department of Anthropology \\ Faculty of Social and Political Sciences, Universitas Airlangga \\ Address: Jalan Dharmawangsa Dalam, Surabaya 60286 \\ E-mail: anifathurohmah06@gmail.com
}

\begin{abstract}
Leuit is a grain bin and has a function to store the community's rice grains of Suka Puyuh Village. This research aims to describe the preservation effort of Leuit in Suka Puyuh Village. Leuit has been preserved through family trait, Leuit reactivation program, and exploiting ruwat lembur tradition as the mechanism. The villagers' attempts to preserve the Leuit intrigued the researcher to conduct further research concerning the existence of the Leuit in Suka Puyuh Village. This research is an ethnographic research along with employing a descriptive method and qualitative approach. Further, the technique of data collection uses observation methods and depth interviews. The obtained data are analyzed using Wilbert E. Moore's Social Change theory. The results of this study indicate that Leuit in Kampung Suka Puyu's community life has undergone a shift because of the change of social structure. Development of the agricultural system from simple to a more advanced and varied level has an impact on the shift of farming system to gardening system.
\end{abstract}

Keywords: preservation, Leuit, ruwat lembur, social change

\section{Introduction}

Indigenous peoples and traditional agriculture are objects of cultural studies that cannot be separated. The term indigenous people is used in simple communities and lives in simplicity. Meanwhile, traditional agriculture exists in indigenous peoples who live in simplicity. Usually, this simplicity is seen from how people process the environment through traditional methods.

The development of an agricultural society is marked by the existence of a permanent agricultural system. The development is based on the lowland rice system and the upland rice system. The lowland rice system is a sustainable system where planting in one place but does not reduce soil fertility makes agricultural yields decline from year to year. Meanwhile, the upland rice system is a system related to shifting cultivation.

The development of agricultural systems from a superficial level to a reasonably advanced level is a form of adaptation to the natural conditions in the environment. This adaptation is seen in behavior based on the problems at hand. Thus, this adaptation is called cultural adaptation (Soemarwoto 1994).

The emergence of Leuit is a form of adaptation of the Suka Puyuh Village community to the environment based on the concept of food security. Public awareness of food security is relatively high. Leuit is a form of food security concept developed by local communities based on existing socio-culture. The Leuit building's presence is a concrete form of the culture of a society, one of which is the Sundanese people who live in Suka Puyuh Village. The form of culture includes three aspects: ideas, activities, and artifacts (Koentjaraningrat 2009). Based on the three forms of culture described by Koentjaraningrat, the shape of the Leuit building in Suka Puyuh Village is the result of a series of ideas, thought, activities, or behavior and artifacts owned by the community. That is manifested in order to support the community's culture, which is manifested in symbols.

Research by Lukita, Tulistyantoro, \& Kattu (2016) entitled "Studi semiotik ruang hunian tradisional Suku Sasak (studi kasus Dusun Sade, Lombok Tengah)" or semiotic study of traditional residential 
spaces of the Sasak Tribe of Sade Hamlet, Central Lombok. This research shows that the people of the Sasak tribe in Lombok also have a form of culture in the form of a rice barn, especially rice farmers. The formation of a rice barn functions as a storage area for rice harvested from rice fields. The rice barn's shape that rises above the goal is so that rodents and other kinds of pests cannot enter the rice barn. Besides, the rice barn is used as a symbol of the prosperity of the Sasak people.

In Hermawan's research (2014) entitled "Bangunan tradisional Kampung Naga: bentuk kearifan warisan leluhur masyarakat Sunda" or traditional building of Kampung Naga: a form of ancestral wisdom of the Sundanese community shows that the rice granary system used in the Kampung Naga community is the fee system. Each resident handed over two bunches of dry rice to be put into the granary. All residents give part of their harvest in the framework of public interests and customary interests.

The strong influence of today's developments has resulted in several cultures in a society experiencing a decline in their role. Rapid technological advances mark this development. The basic assumption is that everything in life changes, whether these changes change by itself or by external influences. The presence of the Leuit is a testament to the simple technology that currently has decreased its role in people's lives.

Research of Imswatama, Saprudin, \& Widyanto (2017) entitled "Etnomatematika arsitektur lumbung padi "Leuit" di Kawasan Geopark Ciletuh Sukabumi sebagai pembelajaran matematika di sekolah dasar" or "Leuit" rice granary architecture ethnomatematics in the Ciletuh Sukabumi Geopark Area as mathematics learning in elementary schools. The results showed that the fading of the Leuit culture in the Geopark area people was caused by the development of information and the strong current of globalization. Efforts made by the Geopark Area people in preserving Leuit are by integrating education in schools with culture. The form of integration, namely the application of ethnomathematics learning because in the Leuit architecture, there are mathematical elements including geometry, thesis/tiling, and similarity.

This problem is also felt in life in the Suka Puyuh Village community. The people's culture of storing rice in Leuit to support food security has now almost been abandoned. Therefore, this research focuses on Leuit conservation efforts carried out by the people of Suka Puyuh Village.

The research was conducted by describing the main problem, namely the conservation of the Leuit in Suka Puyuh Village, and Figure 1 shows the research location. The researcher was interested in researching Leuit Conservation Efforts in Suka Puyuh Village, Rancamanggung Village, Tanjung Siang District, Subang Regency, West Java Province.

In this research, the theory is Wilbert E. Moore's Theory of Social Change, which views social change as a change in social structure in society such as norms, values, behavior patterns, and social interactions. Social change includes all aspects of life that are continually changing. Social changes in society are caused by supporting factors, both external and internal encouragement, that encourage people to take action or deeds (Indraddin \& Irwan 2016).

The formulation of the research problem is expressed to find out the Leuit conservation efforts carried out by the people of Suka Puyuh Village in maintaining and maintaining Leuit in depth. The efforts to conserve Leuit in Suka Puyuh Village are the impact of changes in the social structure that have moved people to maintain their local wisdom culture. Changes in the Suka Puyuh Village community's social structure were triggered by the development of the agricultural system from a superficial level to a more advanced and varied level, leading to changes in the rice field farming system to the garden farming system. Then, the changes in the agricultural system impacted shifting the use of Leuit in the lives of the people of Suka Puyuh Village. The form of shift seen from the use of Leuit, which was initially used as a fulfillment of primary needs, turned into social prestige in society. 


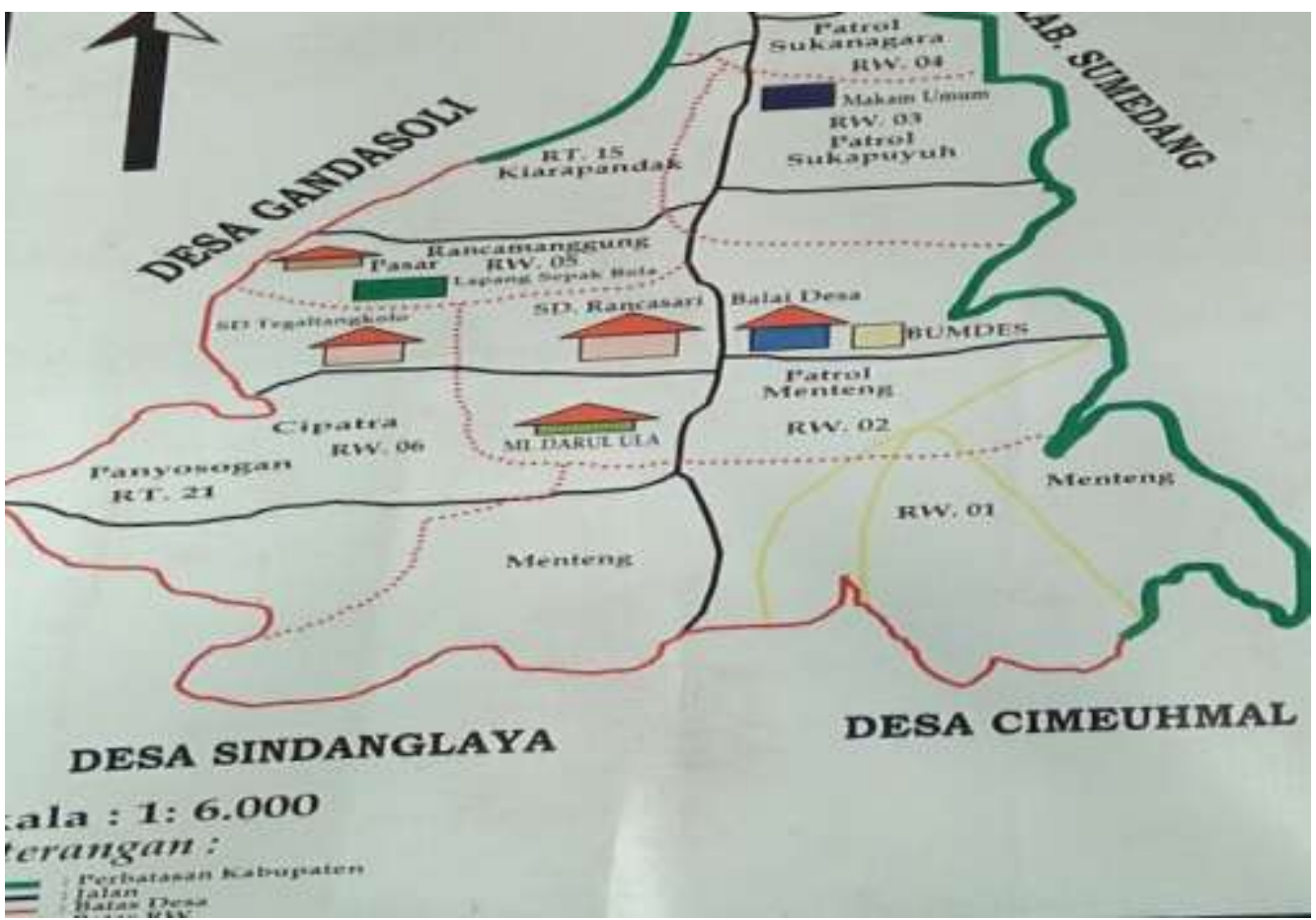

Figure 1

Map of Suka Puyuh Village in Rancamanggung Village

(http://desarancamanggu-tanjungsiang.blogspot.com)

\section{Methods}

In research on Leuit conservation efforts in Suka Puyuh Village, Rancamanggung Village, Tanjung Siang District, Subang Regency, West Java Province, researchers used qualitative methods to answer the problems in this study.

In this study, to obtain data, of course, a data collection technique is needed. Researchers in data collection used several data collection techniques related to Leuit conservation efforts in Suka Puyuh Village. The research was carried out from September 14 to September 15, 2019. Then, the research was continued again from December 17, 2019, to January 1, 2020. The time used for the research was quite long because to know and understand in depth about the efforts to conserve Leuit in Suka Puyuh Village and establish a rapport with the head of the hamlet, traditional leaders, religious leaders, and the community of Leuit owners.

The data collection technique is done by using data collection techniques with the observation method. This method is carried out because it can help researchers make direct observations about conditions in the field related to the Leuit conservation efforts carried out by the people of Suka Puyuh Village. The method of observation carried out by the researcher used the open observation method, which was known by all the people of Suka Puyuh Village. Observations were made on September 14, 2019. Researchers made observations on the object of research, namely Leuit starting from the shape, size, position of the Leuit, color, and other parts of the Leuit. During observations in the field, researchers are not just observing. However, the researcher also took photos/documentation of the research object to explain the research results in the field. Through taking documentation, it is hoped that it can provide a direct picture of the situation in the field regarding the Leuit conservation efforts in Suka Puyuh Village. 
Fathurohmah \& Prasetyo: Shifting the use of Leuit in agricultural systems

In this study, researchers used interview techniques. Using interview techniques, researchers can obtain in-depth information about the conservation of Leuit in Suka Puyuh Village. In this study, researchers used a structured interview technique with in-depth interviews to obtain data information, namely, In-depth Interviews. To get detailed and comprehensive information, the researcher needs to establish a rapport by first approaching the informant before the interview takes place. The goal is so that informants quickly want to provide information as expected by the researcher. The method used by researchers to get a reciprocal relationship with the Suka Puyuh community is by participating in the activities carried out by the community both in farming and in the traditions that are carried out. In this way, researchers can mingle and be able to build a good rapport with the community.

Researchers determine informants based on Spradley (1997), namely full enculturation, direct involvement, unfamiliar cultural atmosphere, sufficient time, and non-analytic. The researcher's interview technique is by asking questions that have been arranged in the interview guide. The interview guide functions so that the informants' information does not come out of the discussion of the research problem. Researchers try to build a comfortable and relaxed atmosphere so that informants do not feel awkward or tense. Researchers provide freedom to informants in answering any questions given by researchers. Researchers also used small notebooks and recording aids via cellphones during the interview process.

\section{Results and Discussion}

The word Leuit comes from the Sundanese language, generally referred to as a rice barn, a particular form of building that functions to store rice. The ideas and ideas expressed in Leuit are a picture of the Suka Puyuh community's socio-cultural condition. Building materials use materials of natural origin such as tiles, bamboo, wood, and stone. Besides, the shape and size of the Leuit are made according to the needs of its function.

The form of Leuit (Figure 2), which is owned by the people of Suka Puyuh Village, resembles a stage house in a pelvis. The Leuit initially resembled a rectangular shape, but seeing the building's condition, which was already rickety, encouraged the community to improve the building's condition so that the rectangular shape was no longer visible. The rectangular shape is a description of the pillars of Islam. It is equipped with a height of 3 meters and 1.5 meters wide, equipped with a Leuit roof, Leuit body, and Leuit foot. Some parts of the Leuit building include; roof, frame, pangaret, pamikul, usuk, batten, jurek, gagalur, pane'er, darurung, door, pole, and tatapakan. Connecting parts of the building to other parts of the building do not use nails, but by giving holes in the parts of the building for connections. Some examples of the shape of the leuit section can be seen in Figure 3 until Figure 5. 
Indonesian Journal of Social Sciences Volume 12 No. 02, July - December 2020, page 85-95

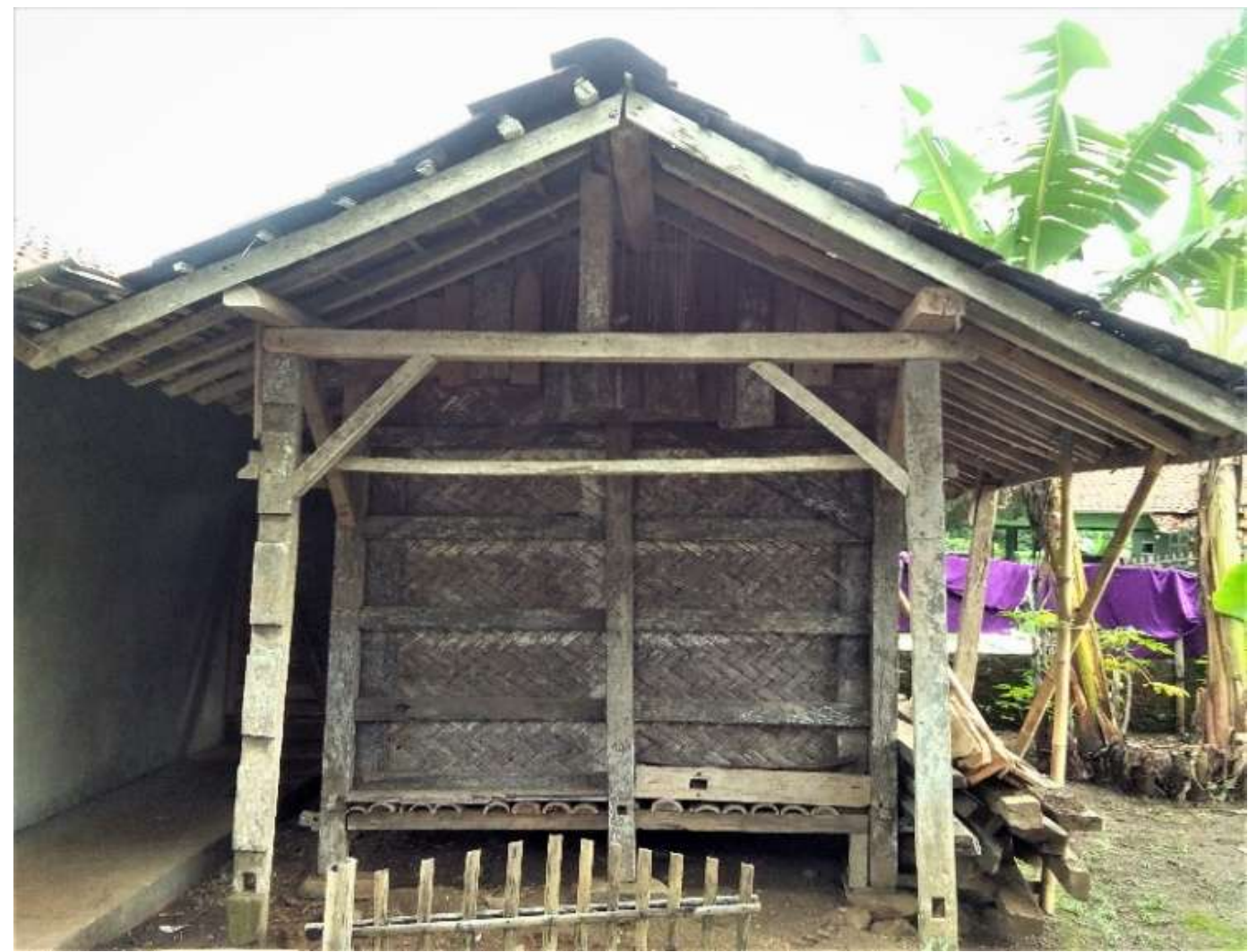

Figure 2

Leuit induk Suka Puyuh

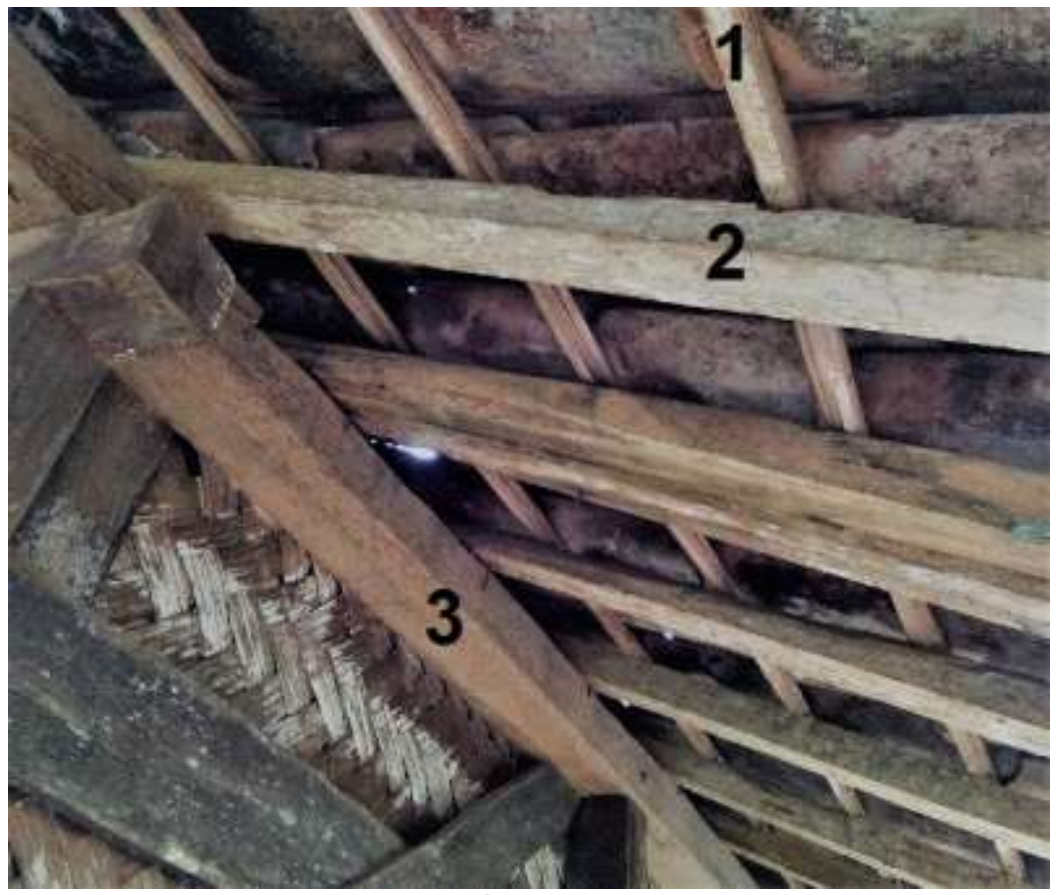

Figure 3

Parts; 1) reng, 2) usuk, and 3) pamikul 


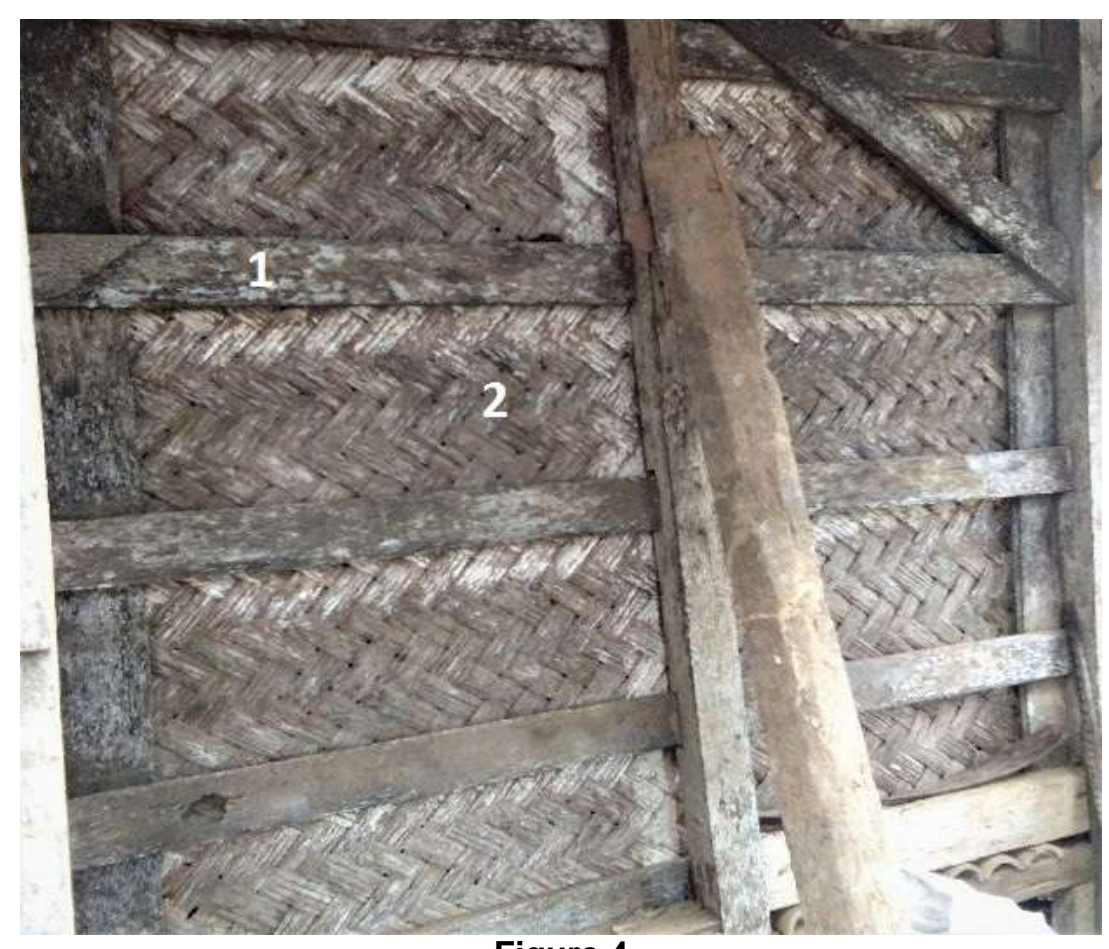

Figure 4

Parts; 1) pane'er, and 2) chamber of kepang tanyjer

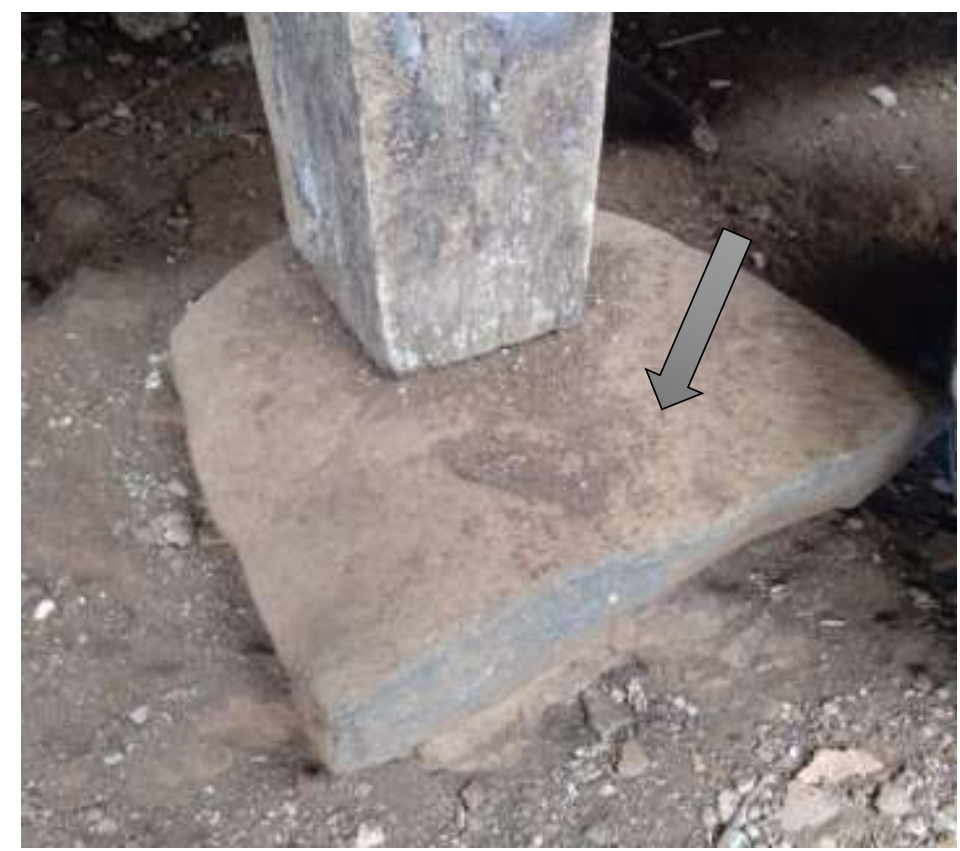

Figure 5

The arrow points to the shape of tatapakan

The Leuit only has one space, which is used to store rice. The rice put into Leuit is not like rice in general, but a type of huma rice. Often, huma rice is referred to as field rice because the cultivation 
system is in the fields or dry land. One Leuit can store up to 100 bunches of gegesan rice and can last for a long time.

In general, the Leuit is placed around the house, either beside or in front of the house, according to the land's condition that is still empty. In general, all Leuit buildings face south. In building Leuit, there was no outstanding designer but the community itself, because Leuit Suka Puyuh has a relatively simple shape so that all people can do it.

Leuit, which is present in the lives of the people of Suka Puyuh Village, is a form of food defense or savings provided by the community in unwanted things. For example, rice in Leuit is used as a food reserve for the community in a prolonged dry or dry season. The system applied to Leuit uses a form of savings and loans. For anyone in the community who experiences food shortages before the main harvest arrives, the community can borrow rice in Leuit according to the amount needed. When the main harvest has arrived, people who borrow rice from Leuit are obliged to return it according to the amount borrowed. Rice returned to Leuit must use the huma rice type. Besides, rice that has been borrowed must be returned using rice, not using money or anything else. People who do not return the rice that has been borrowed will get consequences such as experiencing mental illness.

In the Suka Puyuh Village community, there are two kinds of Leuit, the first is general Leuit, and the second is individual Leuit. Usually, public Leuit is called the main Leuit. It is called a general Leuit, because it was the first Leuit made by the ancestor of Suka Puyuh Village, named Eyang Isbah, with his friend, Ibu Tewang. Meanwhile, private Leuit is called the Leuit branch or child of the Leuit induk.

The people who own the Leuit are those who are native to Suka Puyuh Village or seven generations of descendants of Eyang Isbah. Usually, one Leuit is owned by one offspring. The Leuit tenure system must not leave the family lineage. One Leuit building will always be passed down from generation to generation to their children and grandchildren continuously. For Leuit heirs, there are no rules or regulations to whom it is inherited or inherited, but to those children who are entrusted with maintaining a mandate, be it male or female, be it the first or second, third, and so on. However, beforehand the first child is offered first to make sure whether he is ready or not to maintain the Leuit trust. When the first child is not ready, it can be given to other children.

\section{Leuit conservation efforts in Suka Puyuh Village}

The rapid flow of modernization during people's lives has become one of the challenges for Suka Puyuh Village in maintaining the existence of their local culture. The era of modernization, marked by the rapid development of technology, resulted in several cultures experiencing a decline in their role in people's lives. Leuit building is an example of a cultural form that has begun to be eroded by the current modernization.

The effort of the Suka Puyuh community in defending Leuit was the first time made by the family. Leuit is only owned by a family included in the seven descendants of the Suka Puyuh ancestor. The family itself started the first steps taken by the Suka Puyuh Village community in defending Leuit. In the established customary rules, there are rules that the Leuit must be passed down from generation to generation to its parent-child and must not leave the family line.

The second effort was made by all the people of Suka Puyuh Village to keep together in preserving Leuit. The Suka Puyuh community is trying to recompile the Leuit program to reactivate the Leuit concept in people's lives. The Suka Puyuh community and traditional village institutions are trying to redevelop the Leuit program as the Leuit building is used. Later the customary village institution, this program will be submitted to the Subang Regency Regional Government to request financial assistance. By redeveloping the Leuit program, the Suka Puyuh community took the initiative that the rice stored in Leuit was not huma rice, which was rubble. However, lowland rice seeds are more accessible and more practical. 
The tradition of ruwat lembur as a mechanism for the Suka Puyuh community in preserving Leuit

The Suka Puyuh community's efforts in defending Leuit are not only carried out through the family lineage and the Leuit program, which will be reactivated. However, efforts to conserve Leuit are also carried out by utilizing the tradition of ruwat over time as a community mechanism in maintaining the existence of Leuit in Suka Puyuh Village. Once a year, the Leuit building in Suka Puyuh will be performed ruwat in the ruwat lembur tradition. In the ritual, the Leuit building will be given offerings as a symbol of community wartos to the ancestors of Suka Puyuh.

In the earth thanksgiving event, everything related to agricultural produce will be served in a ruwat overtime program, such as the community's agricultural products ranging from fruits, spices to vegetables. The food served in the ruwatan event depicts all forms of life of the Suka Puyuh community that originate from the earth. Whatever the form that supports people's lives, all originate from the earth and return to earth again. The community considers that the agricultural products presented are a symbol of the term wartos or informing the gods and ancestors who have founded Suka Puyuh Village about the results of the community's efforts to get blessings in life. All types of food used as a symbol for the ruwatan event will also be placed in the Leuit building. Thus, there is a relationship between the Leuit building and the ruwat lembur tradition carried out by the Suka Puyuh community.

Leuit is a remarkable building that is used as a place to store rice. Rice/rice stored in Leuit is a food eaten by the Suka Puyuh community in their daily life. The food served at Leuit during the ruwatan event has something to do with the content in Leuit, namely rice. Rice comes from the earth, and the food that is served all also comes from the earth. So, the food served with the contents in Leuit has the same origin, namely from the earth. Thus, everything related to agricultural products by the Suka Puyuh community will be ruwat in a village thanksgiving event in the month of Muharram.

Several types of food served in the soft ruwat tradition or the Leuit building, namely red porridge and white porridge, incense, coffee and cigarettes, rurujakan, sawen, and seven forms of flowers.

\section{Law number 5 of 2017 concerning Cultural Advancement}

The Suka Puyuh community's efforts in defending the Leuit were strengthened by the formation of traditional institutions in the village of Rancamanggung and the emergence of Law No. 5 of 2017 concerning the Advancement of Culture. Efforts regarding the advancement of culture carried out by all circles of society need a legal umbrella used as a guide in the advancement of culture in an integrated and comprehensive manner. The purpose of Law Number 5 of 2017 concerning Cultural Advancement is stated in Article 1 Paragraph 3, namely, to increase cultural resilience and contribution of Indonesian culture amid world civilization through the protection, development, utilization, and fostering of culture.

The purpose of the formation of the Law on Cultural Advancement is contained in Article 4, namely, to (a) develop the noble values of the nation, (b) to enrich cultural diversity, (c) to strengthen the national identity, (d) to strengthen the unity and integrity of the nation, (e) ) educating the nation's life, (f) enhancing the image of the nation, (g) creating a civil society, (h) increasing people's welfare, (i) preserving the nation's culture, and (j) influencing the direction of the development of world civilization. In this way, a culture can be used as the direction of national development.

The main targets or objects of the Republic of Indonesia Law Number 5 of 2017 concerning Cultural Advancement written in Article 5 include; (a) oral traditions, (b) manuscripts, (c) customs, (d) rituals, (e) traditional knowledge, (f) traditional technology, (g) arts, (h) language, (i) folk games, and the last (j) traditional sports.

Leuit in Suka Puyuh Village is one of the target objects of the Republic of Indonesia Law Number 5 of 2017 concerning Cultural Advancement. As written in Article 5 section (f), traditional technology 
talks about rice field processing tools, architecture, irrigation systems, and transportation tools. Leuit building is architectural in the traditional technology referred to in Article 5 (f). Leuit is a simple technology currently amid the dynamics of world civilization - faced with the increasingly rapid development of technology. It is a big challenge for the Suka Puyuh community to maintain Leuit. Thus, the government needs to be a strategy to become an umbrella for the existence of local cultures such as Leuit.

\section{Changes in the social structure of the Suka Puyuh Village Community}

The change in the Suka Puyuh Village community's social structure was triggered by a change in the agricultural system from a superficial level to a more advanced and varied level. In the 70's the agricultural system of the Suka Puyuh Village farming community was still not developed. Lack of knowledge about the cropping system causes the development of the community farming system to experience delays. The knowledge system applied to the agricultural system used local knowledge inherited from the ancestors of Suka Puyuh Village, such as fertilizers applied to agricultural crops as a type of manure. In the 70s, people were not familiar with kimai fertilizer. When applied to crops, lack of manure types, from the beginning of planting to waiting for the harvest to arrive, takes a long time. Also, farmers often experience failures in farming due to a lack of knowledge about planting.

These problems move the Subang Regency regional government to provide counseling on farming systems based on modern agricultural systems such as those in Lembang and Ciater. Then, since the 80s until now, the farming system changes in Suka Puyuh Village have grown quite rapidly. The community's knowledge for outreach is implemented in their agricultural system in the fields and the garden. Since then, the community has no longer experienced farming failures, and the income of the community's economic system has increased. The agricultural system has become very varied, which initially only relied on cultivating upland rice, then moved on to planting lowland rice and the emergence of a palawija system that varied greatly from spices, vegetables, and fruits.

With the development of an advanced and varied agricultural system, Suka Puyuh Village people prefer to farm on the plantation system than on rice fields. The plantation system is considered to have multiple functions compared to rice fields. The rice field system can only be planted with one type of plant, namely rice, in contrast to gardens. The plantation system can be planted with more than one crop. For example, 100 tumbak in rice fields can only be planted with one type of plant, namely rice. However, 100 tumbak in the garden can be planted with cassava, peanuts, kencur, corn, and others. That way, the plantation system's income will be double compared to the income from rice fields. The rice field farming' system results are only used as a means of food provision for the people of Suka Puyuh Village.

The change in the paddy field farming system to the garden farming system was one of the factors that caused the loss of the culture of the people of Suka Puyuh Village storing rice in Leuit. This habit is carried out at the time of the main harvest. After harvesting, all of the rice is put into Leuit as a food supply. However, with the change in the agricultural system, Suka Puyuh Village people began to abandon this culture. The existence of Leuit is starting to disappear one by one because the Suka Puyuh community places more emphasis on the garden farming system, which is used as a buffer against the economic system. However, not all people Suka Puyuh let Leuit disappear. Four Leuit buildings are still being preserved and maintained today.

Leuit still exists and exists in the lives of the people of Suka Puyuh Village, but it has undergone cultural changes in its use. In terms of building function, Leuit is used as a storage area for rice from the fields' harvest. The rice stored and put into the Leuit becomes the community's rice stock for the upcoming harvest season. If there are members of the community who experience food shortages, the community can borrow rice from Leuit. Rice itself is a staple ingredient that is processed into the form of rice to be used as food eaten in the Suka Puyuh community's daily life. With the presence of Leuit in the community, it helps the Suka Puyuh community meet their food needs. Leuit was formed 
to aim that no one of the Suka Puyuh people would experience hunger or run out of food in the shortcoming season. That is the function of the Leuit as a function of the people of Suka Puyuh village.

However, changes in the current agricultural system have been able to shift the use of Leuit in the community of Suka Puyuh village. Leuit is no longer used to store rice. Leuit is currently only used as a cultural object that is guarded and preserved by the community. One of the Leuit preservation efforts carried out by the Suka Puyuh community is utilizing the ruwat overtime tradition, which is carried out once a year in the month of Muharram. In the ruwat lembur tradition, there is a special ritual performed at the Leuit building, namely sawen. Leuit will be sawen using several types of food such as kupat, lepet, tang tangangin, opak, krangginang, sarawung, palias leaves, and rurujakan. These foods will later be hung on the Leuit building using the leaves of the noue tree.

The values of expression carried in the ritual activity represent the lives of Suka Puyuh Village. Whereas, the rice content in Leuit with the food served in the ritual has the same origin, namely from the earth, and is food eaten by people daily. The seven types of food hanging on the Leuit represent the seven types of human self-control that can be controlled. Seven of this self-control, such as the eyes can see, the nose can inhale, the mouth can speak, teeth can chew, ears can hear, hands can move, and feet can walk. The seven types of food that the Leuit depends on when eaten will become energy and can generate seven self-powers in the human body.

Changes in the use of Leuit in the Suka Puyuh Village community's socio-cultural life have also led to the emergence of social prestige. Given that, Leuit is only owned by the indigenous people who are seven generations of the ancestral village of Suka Puyuh Village. Leuit ownership will continue from generation to generation and cannot be separated from the family lineage. Derived from this background, people who own Leuit are seen as different as if they have a different position in the Suka Puyuh community's life order. Usually, the community is more respected and respected by other community members. Such behavior can be found directly in the daily life of the Suka Puyuh community. Not only in the Leuit ownership system, the seven generations who are descendants of Eyang Isbah are also people who hold traditions and customs or are often referred to as traditional leaders. The customs in Suka Puyuh Village are led directly by the descendants of the ancestors of Eyang Isbah. This position will always be passed down from generation to generation directly to the offspring and so on.

\section{Conclusion}

We can know that culture still exists today because it has a particular function in people's lives, likewise with the Leuit, which still exists and continues to exist in the Suka Puyuh Village community. In research on Leuit Conservation Efforts in Suka Puyuh Village, Rancamanggung Village, Tanjung Siang District, Subang Regency, West Java Province, researchers found several Suka Puyuh community efforts in maintaining Leuit amid rapid technological development. The first attempt was made by the family unit, where the Leuit was only owned by a family belonging to the seven descendants of the ancestors of Suka Puyuh Village. In this family, Leuit will always be passed on to their children and grandchildren. There is also a provision that the Leuit cannot leave the family lineage in the customary rules. The goal is for the Leuit to remain and be guarded by the native people of Suka Puyuh Village. These efforts by the community were continued by starting to formulate the Leuit program to reactivate the Leuit Function in the life of the Suka Puyuh community.

Leuit is also maintained by utilizing the ruwat overtime tradition as a mechanism for the Suka Puyuh community in preserving Leuit. The tradition of ruwat overtime is carried out once a year in the month of Muharram. This tradition is an impact of the form of food security for the people of Suka Puyuh Village. Therefore, when the ritual of ruwat overtime was carried out, Leuit also participated 
Indonesian Journal of Social Sciences Volume 12 No. 02, July - December 2020, page 85-95

in the ruwat. In the ruwat lembur tradition, there is a special ritual performed at the Leuit building, namely sawen. Leuit will be sawen using several types of food such as kupat, lepet, tang tangangin, opak, krangginang, sarawung, and palias leaves, as well as rurujakan / Leuit's relationship with the ruwat overtime tradition, is in the content in Leuit, namely rice. Rice originates from the earth, and the ruwat lembur tradition is a tradition of thanksgiving shown to the earth. So, everything related / originating from the earth will be ruwat in the tradition of village thanksgiving. The Suka Puyuh community's efforts in maintaining Leuit are strengthened by Law Number 5 of 2017, which talks about the advancement of culture. That is like written in Article 1, Paragraph 3, namely, efforts to increase Indonesian culture's cultural resilience and contribution amid world civilization through the protection, development, utilization, and fostering of culture. In research on Leuit conservation efforts in the Suka Puyuh Village community, the researcher uses the theory of social change proposed by Wilbert E. Moore. The changes in the social structure in the Suka Puyuh Village community were triggered by the development of the agricultural system from a superficial level to a more advanced and varied level, causing a change in the rice field to the garden farming system. Then, the changes in the agricultural system impacted shifting the use of Leuit in the lives of the people of Suka Puyuh Village. The form of shift seen from the use of Leuit, which was initially used as a fulfillment of primary needs, turned into social prestige in society.

\section{References}

Hermawan I (2014) Bangunan Tradisional Kampung Naga: Bentuk Kearifan Warisan Leluhur Masyarakat Sunda. Sosiao Didaktika 1 (2): 141-150.

Imswatama A, Saprudin, \& Widyanto R (2017) Etnomatematika Arsitektur Lumbung Padi "Leuit" di Kawasan Geopark Ciletuh Sukabumi sebagai Pembelajaran Matematika di Sekolah Dasar. In: Prosiding Seminar Nasional Kedua: Pendidikan Berkemajuan dan Menggembirakan (The Second Progressive and Fun Education Seminar) Jati Diri LPTK PTM untuk Pendidikan yang Berkemajuan dan Menggembirakan, 3 Agustus 2017, Mataram. Surakarta: Muhammadiyah University Press, 43-50.

Indraddin \& Irwan (2016) Strategi dan Perubahan Sosial. Yogyakarta: Deepublish.

Koentjaraningrat (2009) Pengantar Ilmu Antropologi. Jakarta: Rineka Cipta.

Letak, Luas dan Aksesibilitas (2017) [Diakses 24 Oktober 2019]. http://desarancamanggutanjungsiang.blogspot.com/2017/08/letak-luas-dan-aksesibilitas.html?m=1.

Lukita IGAV, Tulistyantoro L, \& Kattu GS (2016) Studi Semiotik Ruang Hunian Tradisional Suku Sasak (Studi Kasus Dusun Sade, Lombok Tengah). Dimensi Interior 14 (2): 72-77.

Soemarwoto O (1994) Ekologi Lingkungan Hidup dan Pembangunan. Jakarta: Djambatan.

Spradley JP (1997) Metode Etnografi. Yogyakarta: Tiara Wacana Yogya.

Undang-undang Nomor 5 (2017) Undang-undang tentang Pemajuan Kebudayaan. Lembaran Negara RI Tahun 2017 Nomor 104. Tambahan Lembaran Negara Nomor 6055. 